Supporting Information

\title{
Synthetic Virus-like Particles for Glutathione Biosynthesis
}

Yang Wang ${ }^{1}$, Masaki Uchida ${ }^{2}$, Hitesh Kumar Waghwani ${ }^{1}$, and Trevor Douglas ${ }^{l *}$

${ }^{1}$ Department of Chemistry, Indiana University, Bloomington, Indiana 47405, United

States

${ }^{2}$ Department of Chemistry, California State University Fresno, Fresno, California 93740, United States

*Corresponding Author: Trevor Douglas

Email: trevdoug@indiana.edu

Phone: +1 (812) 856-6936 


\section{Contents}

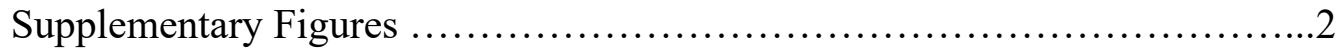

Supplementary Tables $\ldots \ldots \ldots \ldots \ldots \ldots \ldots \ldots \ldots \ldots \ldots \ldots \ldots \ldots \ldots \ldots \ldots \ldots \ldots \ldots \ldots$

Supplementary Methods ............................................ 10

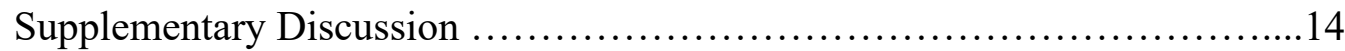

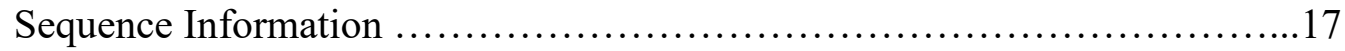

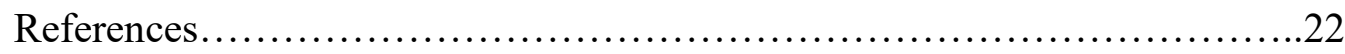




\section{Supplementary Figures}
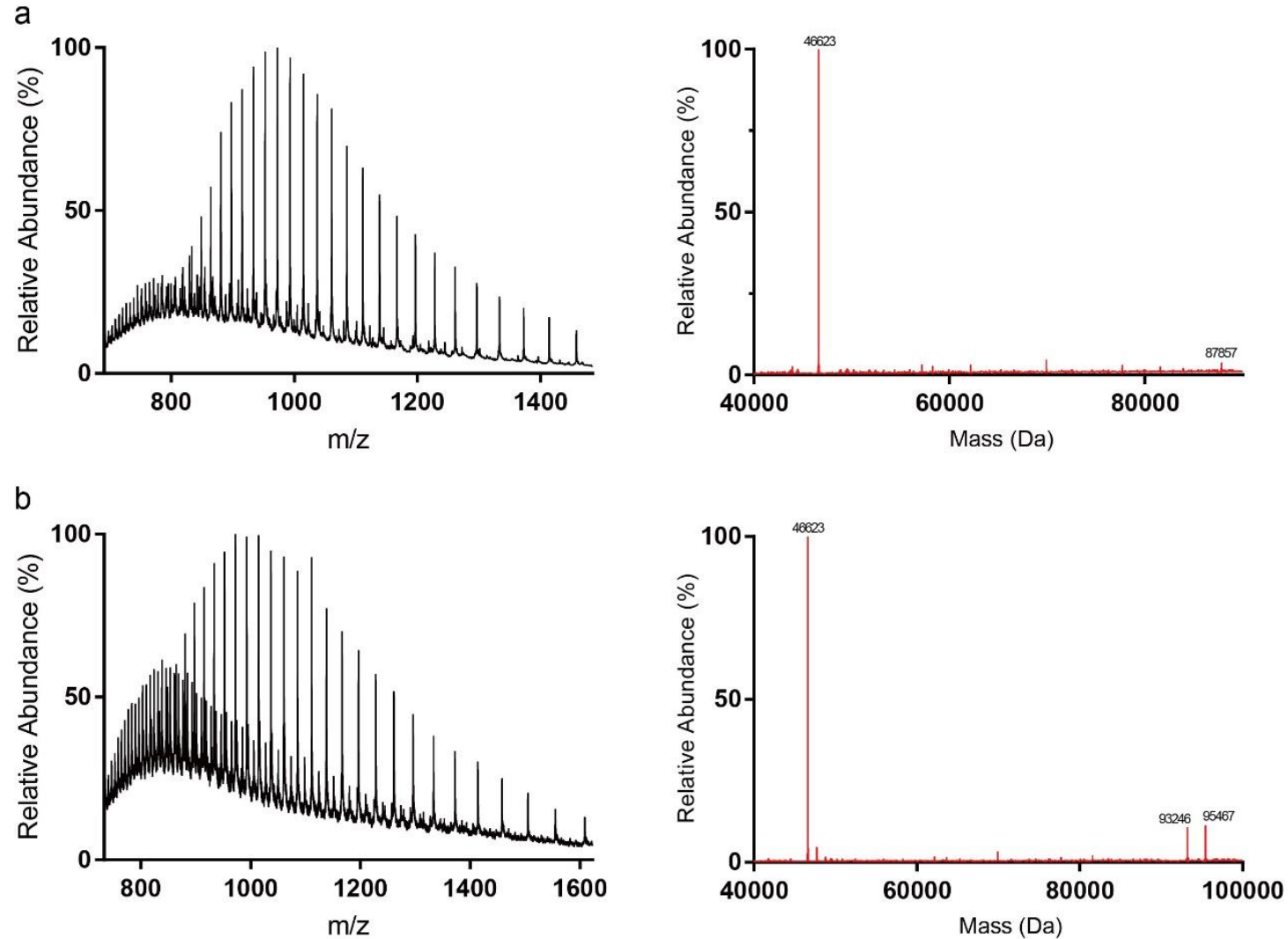

Figure S1. Mass spectrometry results of P22 VLP nanoreactors. (a) P22-GCL. (b) P22-GshF 1 . Left: Raw data plot. Two protein species were detected, showing two peaks. The left peak is from GCL or GshF, while the right high peak is from CP. Right: Corresponding mass plot deconvoluted from the whole $\mathrm{m} / \mathrm{z}$ range of the raw data plot. These results indicate the presence of $\mathrm{CP}$ (expected monomer 46620.67 Da and dimer 93241.34 Da), and complete GCL (expected 87856.29 Da) or GshF (expected $95464.98 \mathrm{Da}$ ). To minimize the interference from the CP, the molecular mass of GCL and GshF was also determined by only deconvoluting the raw data for the GCL peak $(\mathrm{m} / \mathrm{z}$ from 692.4324 to 802.6553 ) and the GshF peak (m/z from 734.7854 to 913.6259$)$, and the results are shown in figure 2. 

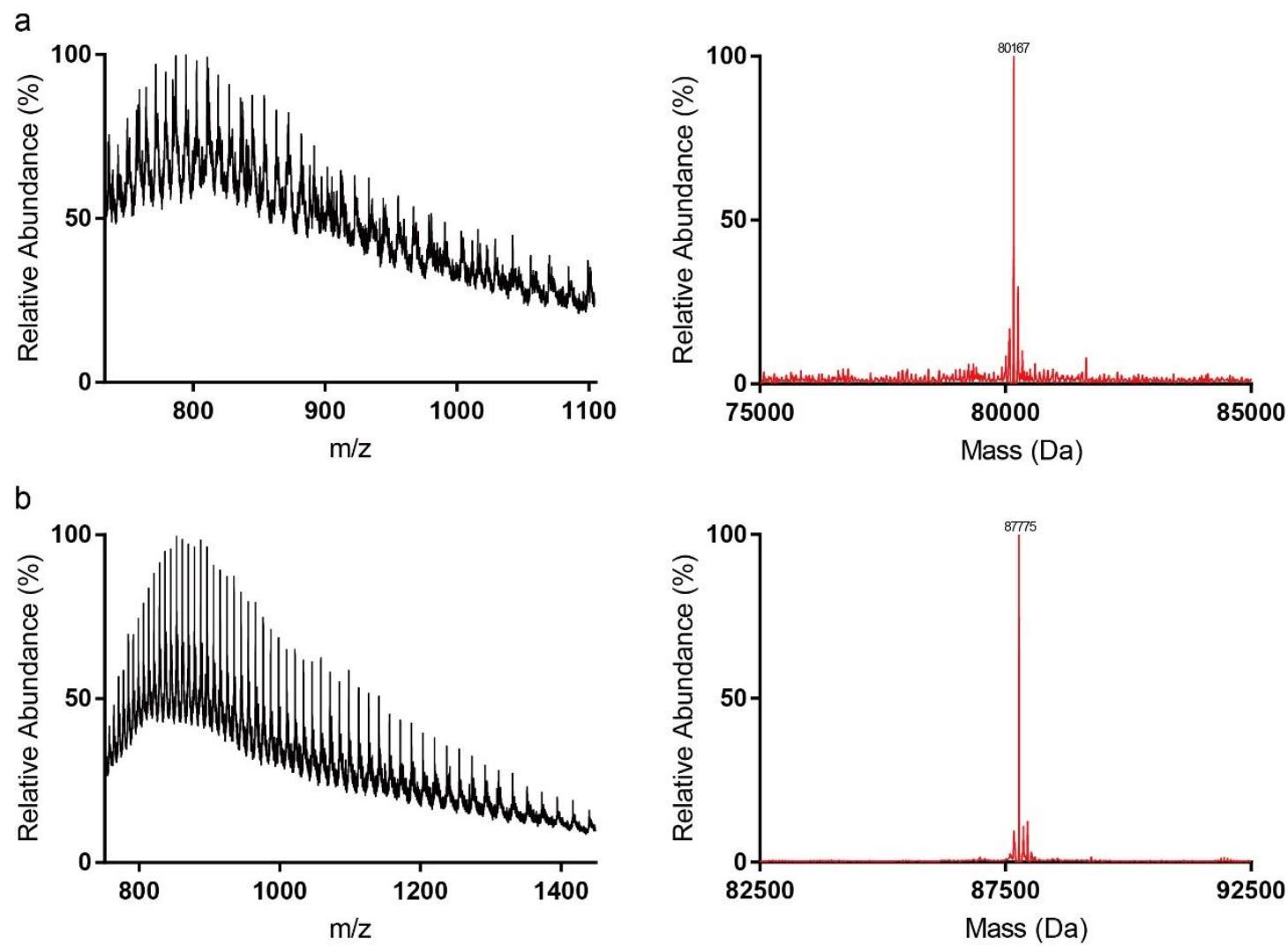

Figure S2. Mass spectrometry results of free enzymes. (a) Free GCL. (b) Free GshF. Left: Raw data $(\mathrm{m} / \mathrm{z})$ plot. Right: Corresponding mass plot deconvoluted from the whole $\mathrm{m} / \mathrm{z}$ range of the raw data plot. The measured mass is different from the expected (87856.29 Da for GCL, and 95464.98 Da for GshF). However, the difference is the same for both proteins (7689.29 Da for GCL, and 7689.98 Da for GshF), indicating the same cleavage (between Y and F within the linker part, noted in the Sequence Information section) happened at a sharing site of both proteins. The expected molecular weights of the cleaved enzymes are 80167.49 Da for GCL and 87776.18 Da for GshF, consistent with the observed masses shown here (80167 Da for GCL and 87775 Da for GshF).
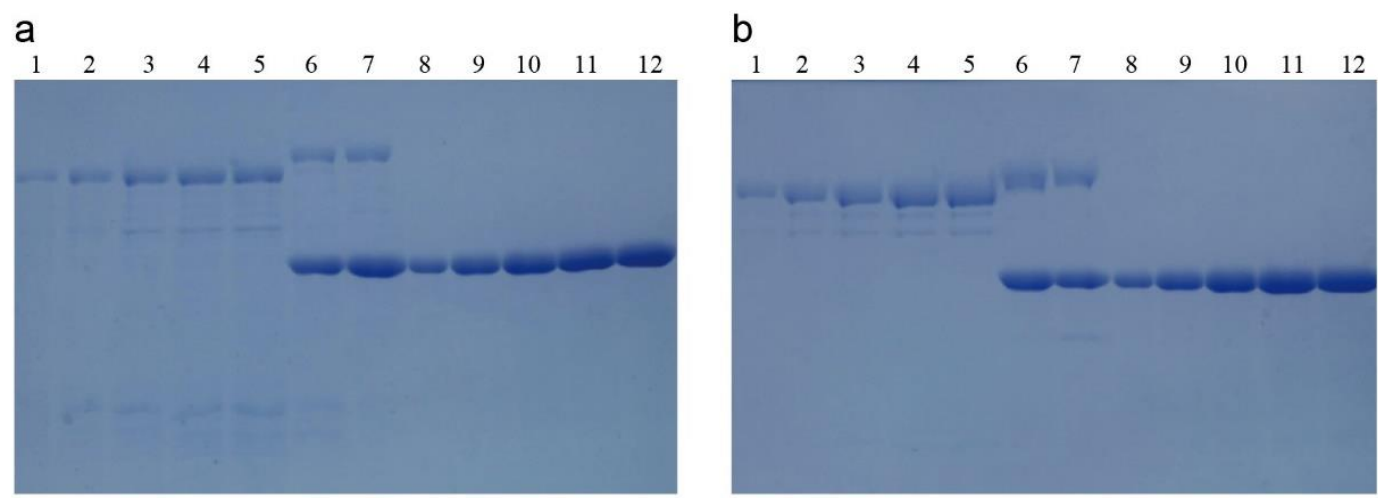

Figure S3. SDS-PAGE densitometry was used to calculated the loading density of enzymeencapsulated VLPs. (a) GCL. (b) GshF. For both gels, lane 1-5, mole gradient of free GCL or GshF $\left(6,12,18,24\right.$, and 30 pmol in monomer); lane $6, \mathrm{P} 22-\mathrm{GCL}_{\mathrm{s}}$ or $\mathrm{P} 22-\mathrm{GshF}_{\mathrm{s}}$; lane $7, \mathrm{P} 22-\mathrm{GCL}_{1}$ or P22- 
$\mathrm{GshF}_{1}$; lane 8-12, mole gradient of empty shell P22 VLPs $(60,120,180,240$, and 300 pmol in monomer).
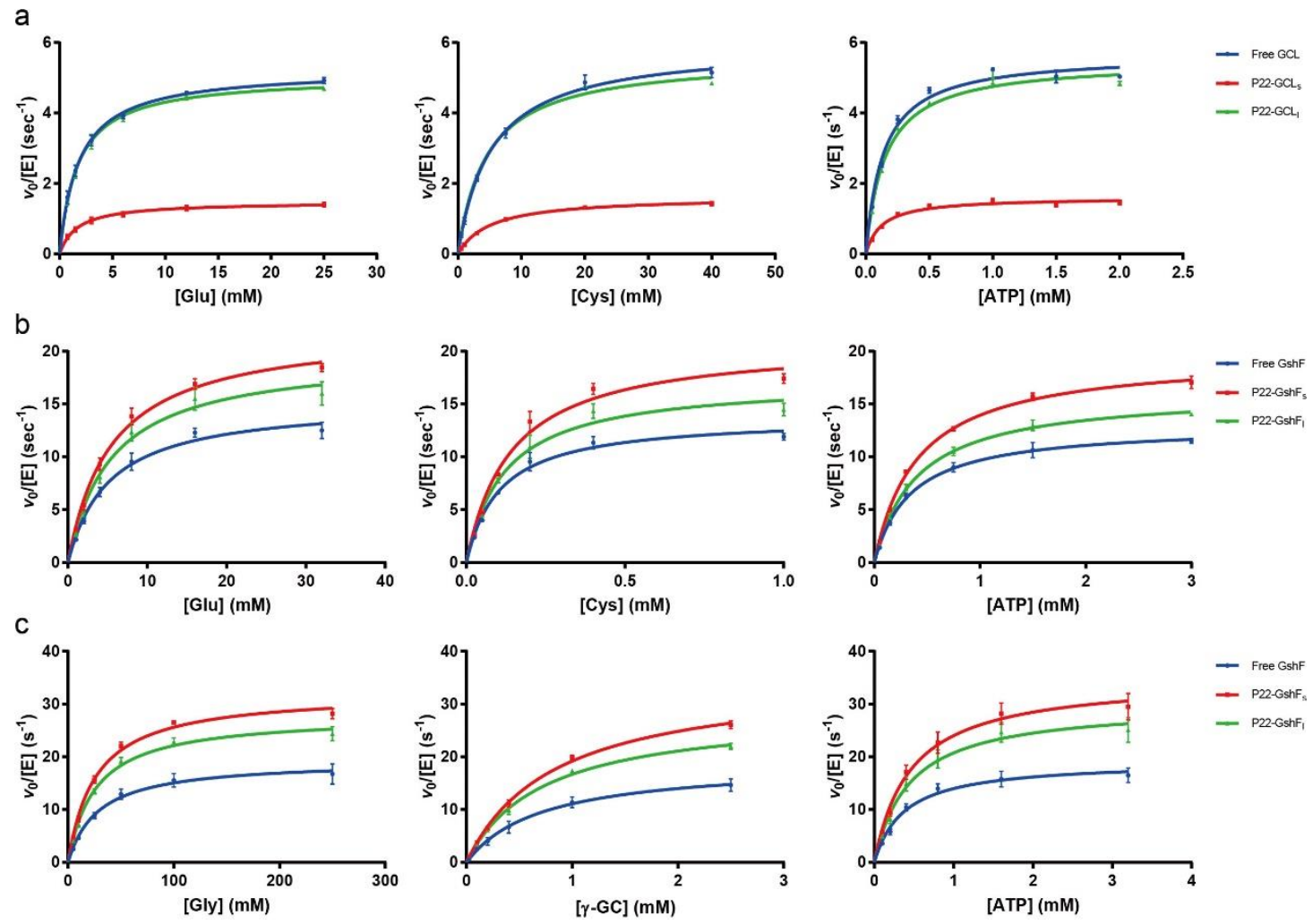

Figure S4. Michaelis-Menten kinetic plots measured by PK-LDH assays ( $\mathrm{n}=3$, supplementary to table 1). All data are expressed as mean \pm s.e.m. $(n=3)$. (a) GCL-catalyzed synthesis of $\gamma$-GC from Glu, Cys and ATP. (b) GshF-catalyzed synthesis of $\gamma$-GC from Glu, Cys and ATP. (c) GshF-catalyzed synthesis of GSH from $\gamma$-GC, Gly, and ATP.

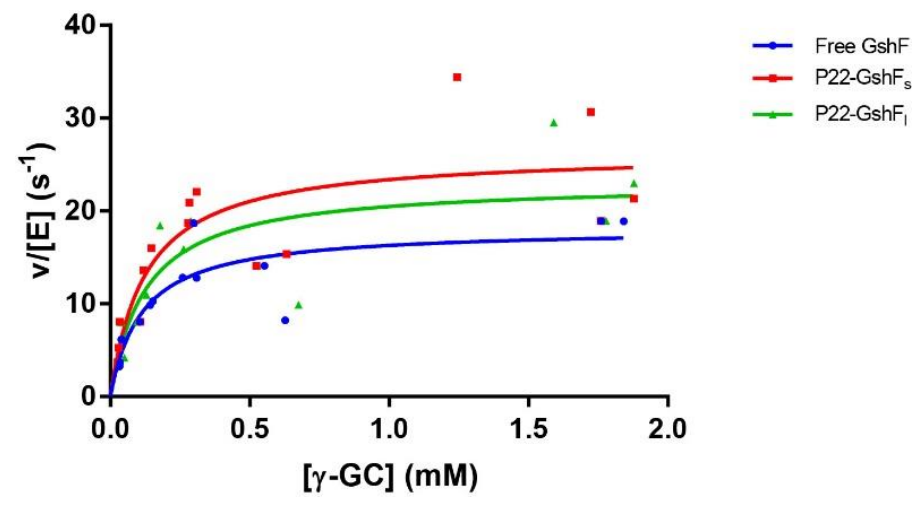

Figure S5. Michaelis-Menten kinetics plot for GshF-catalyzed synthesis of GSH from $\gamma$-GC, 350 $\mathrm{mM}$ Gly, and $5 \mathrm{mM}$ ATP, measured by $\mathrm{mBBr}$ assays. 

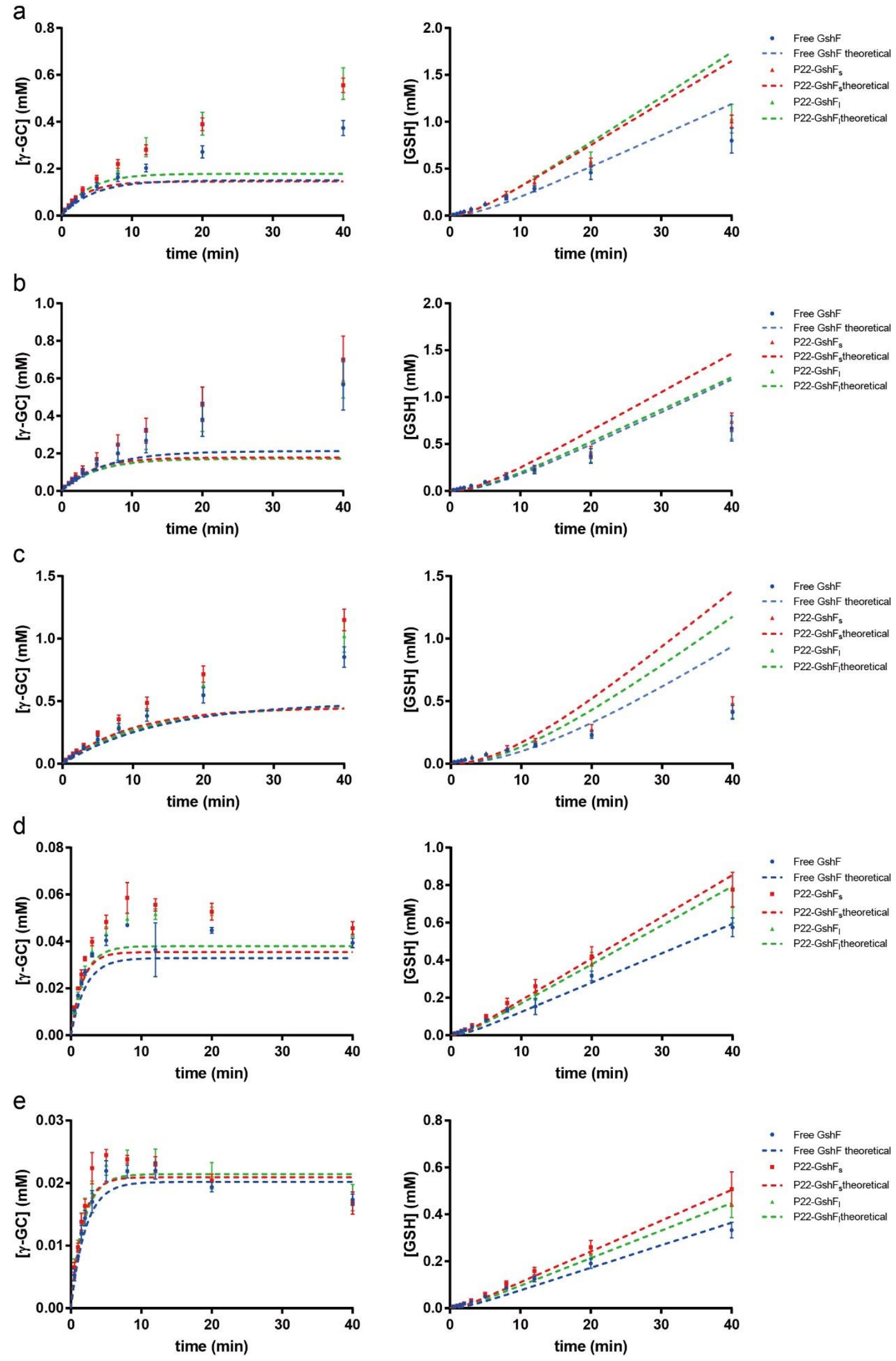

Figure S6. Kinetics study of the GshF-catalyzed complete GSH biosynthetic pathway under variable substrate concentrations (supplementary to figure 3). (a) Reactions carried out at $50 \mathrm{mM}$ 
Glu, 2mM Cys, 25mM Gly, 5mM ATP. (b) Reactions carried out at $50 \mathrm{mM}$ Glu, $2 \mathrm{mM}$ Cys, $15 \mathrm{mM}$ Gly, $5 \mathrm{mM}$ ATP. (c) Reactions carried out at $50 \mathrm{mM}$ Glu, $2 \mathrm{mM}$ Cys, $5 \mathrm{mM}$ Gly, $5 \mathrm{mM}$ ATP. (d) Reactions carried out at $15 \mathrm{mM}$ Glu, $2 \mathrm{mM}$ Cys, $350 \mathrm{mM}$ Gly, $5 \mathrm{mM}$ ATP. (e) Reactions carried out at $5 \mathrm{mM}$ Glu, $2 \mathrm{mM}$ Cys, $350 \mathrm{mM}$ Gly, $5 \mathrm{mM}$ ATP. Left: progress plot of $\gamma$-GC concentration. Right: progress plot of GSH concentration. All data are expressed as mean \pm s.e.m. $(n=3)$.
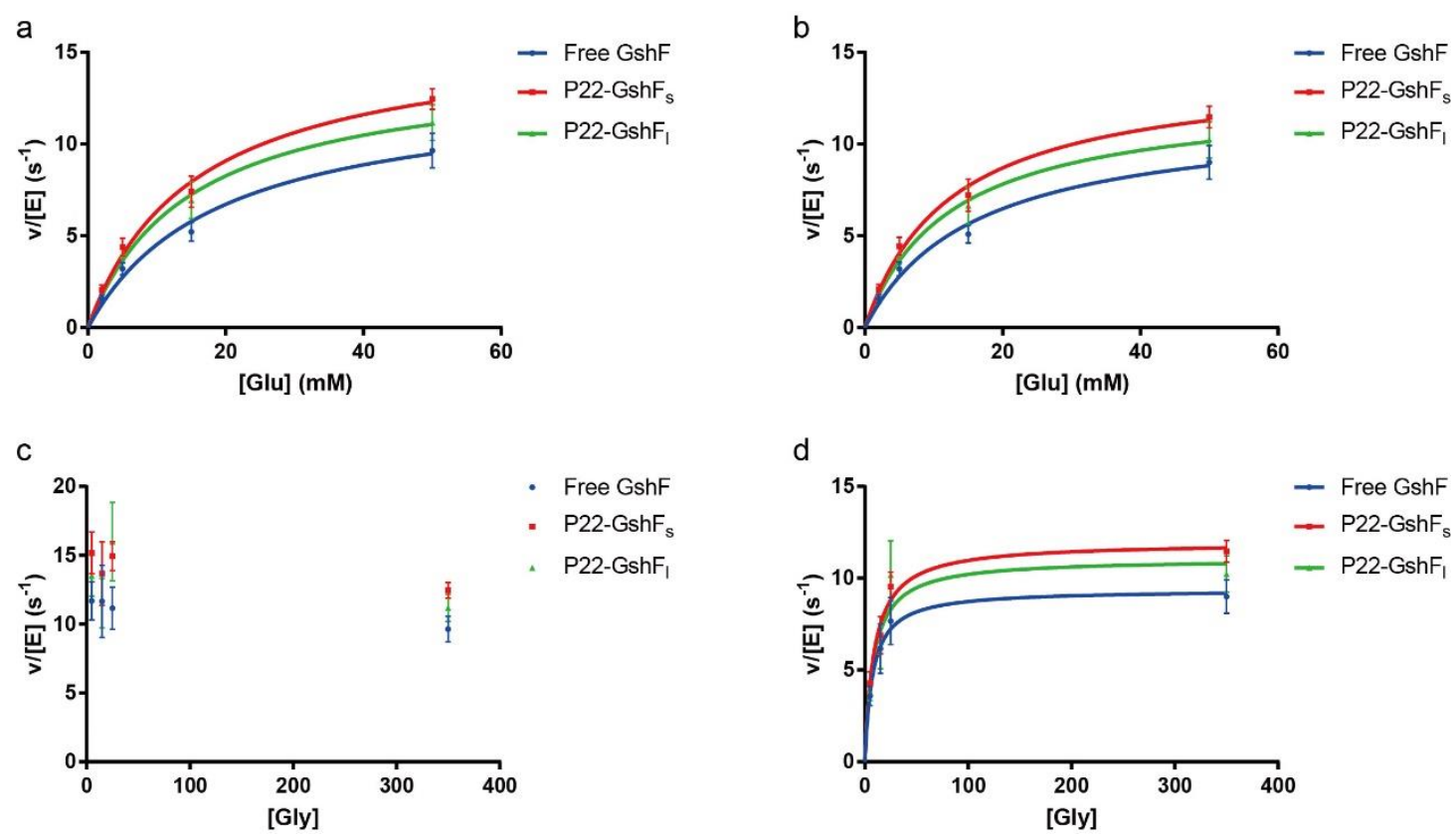

Figure S7. Michaelis-Menten kinetics plots for the complete GSH biosynthetic pathway catalyzed by GshF from Glu, Cys, Gly, and ATP, measured by mBBr assays. (a) The rates of the first step were plotted against [Glu], with fixed concentrations of Cys (2 mM), Gly (350 mM), and ATP (5 mM). (b) The rates of the second step were plotted against [Glu], with fixed concentrations of Cys ( $2 \mathrm{mM})$, Gly $(350 \mathrm{mM})$, and ATP $(5 \mathrm{mM})$. These rates were dictated by the rates of the first step shown in (a), and therefore figure (a) and (b) are very similar. (c) The rate of the first step was plotted against [Gly], with fixed concentrations of Glu $(50 \mathrm{mM})$, Cys $(2 \mathrm{mM})$, and ATP $(5 \mathrm{mM})$. As all three substrates for the first step were saturated, the rates kept close to constants regardless of Gly concentration. (d) The rates of the second step were plotted against [Gly], with fixed concentrations of Glu (50 mM), Cys (2 mM), and ATP (5 mM). 


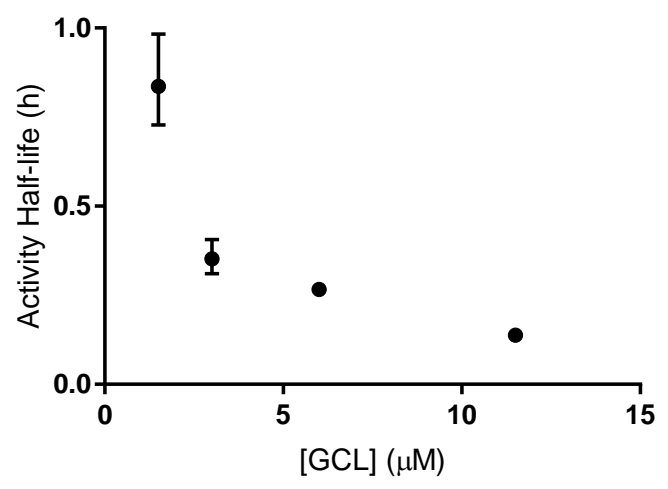

Figure S8. Activity half-life of free GCL. The activity half-life decreases as protein concentration increases, due to an increase in protein aggregation.
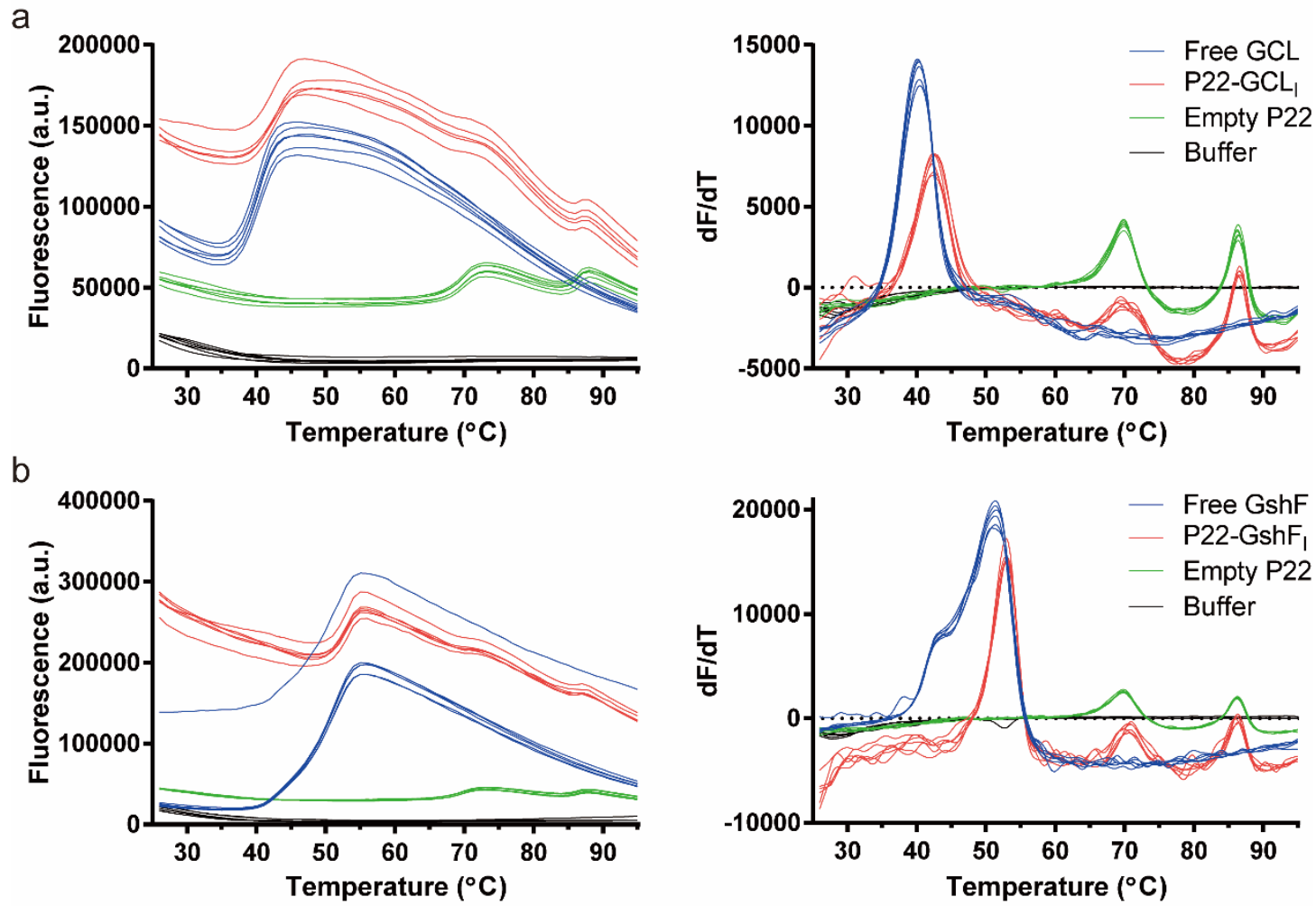

Figure S9. SYPRO Orange dye-based thermal shift assay. (a) GCL. (b) GshF. Left: Thermal denaturation profile. Right: The first derivative of thermal denaturation profile, from which melting temperatures of GCL and GshF were identified (see Table 3). P22 capsids experienced two stages of denaturation at $\sim 71{ }^{\circ} \mathrm{C}$ and $\sim 87^{\circ} \mathrm{C}$, which is consistent with a previous report. ${ }^{l}$ a.u., arbitrary units. 


\section{Supplementary Tables}

\begin{tabular}{|c|c|c|c|c|c|}
\hline Technique & Property & $\mathrm{P} 22-\mathrm{GCL}_{\mathrm{s}}$ & P22-GCL & $\mathrm{P} 22-\mathrm{GshF}_{\mathrm{s}}$ & P22-GshF \\
\hline \multirow{2}{*}{$\begin{array}{l}\text { SDS-PAGE } \\
\text { Densitometry }\end{array}$} & $\begin{array}{c}\text { Packing Density } \\
\text { (enzyme copies per capsid) }\end{array}$ & $119.3 \pm 19.2$ & $89.3 \pm 33.5$ & $137.7 \pm 12.3$ & $135.7 \pm 18.3$ \\
\hline & Local Concentration $(\mathrm{mg} / \mathrm{ml})$ & $374.7 \pm 60.3$ & $280.5 \pm 105.2$ & $469.9 \pm 42.0$ & $463.1 \pm 62.5$ \\
\hline
\end{tabular}

Table S1. Enzyme packing density and local concentration of P22 VLP nanoreactors determined by SDS-PAGE followed by densitometry analysis. All data are expressed as mean \pm s.d. $(n=3)$.

a

\begin{tabular}{|c|c|c|c|c|c|c|}
\hline \multirow{2}{*}{ Enzyme type } & \multicolumn{3}{|c|}{$K_{\mathrm{m}}(\mathrm{mM})$} & \multicolumn{3}{|c|}{$k_{\text {cat }}\left(\mathrm{s}^{-1}\right)$} \\
\hline & Glu & Cys & ATP & Glu & Cys & ATP \\
\hline $\mathrm{P} 22-\mathrm{GCL}_{\mathrm{s}}$ & 1.738 & 5.105 & 0.1282 & 1.382 & 1.519 & 1.442 \\
\hline P22-GCL & 1.734 & 4.559 & 0.1523 & 5.269 & 5.824 & 5.617 \\
\hline $\mathrm{P} 22-\mathrm{GshF}_{\mathrm{s}}$ & 5.531 & 0.1401 & 0.4118 & 22.22 & 20.94 & 19.74 \\
\hline $\mathrm{P} 22-\mathrm{GshF}_{\mathrm{I}}$ & 5.379 & 0.1212 & 0.4049 & 20.00 & 18.65 & 17.59 \\
\hline \multirow{2}{*}{ Enzyme type } & \multicolumn{3}{|c|}{$K_{m}(m M)$} & \multicolumn{3}{|c|}{$k_{\text {cat }}\left(\mathbf{s}^{-1}\right)$} \\
\hline & Gly & $y-G C$ & ATP & Gly & $\gamma-G C$ & ATP \\
\hline P22-GshF & 25.89 & 0.8321 & 0.4543 & 25.11 & 27.39 & 27.20 \\
\hline P22-GshF & 25.93 & 0.7183 & 0.4420 & 21.36 & 21.97 & 22.92 \\
\hline
\end{tabular}

Table S2. Steady-state kinetic constants determined by PK-LDH assay. Supplementary to table 1, these results were processed on the same experiment, but analyzed with loading density obtained from densitometry instead of MALS. (a) Synthesis of $\gamma$-GC from Glu and Cys, catalyzed by GCL or GshF. (b) Synthesis of GSH from $\gamma$-GC and Gly, catalyzed GshF.

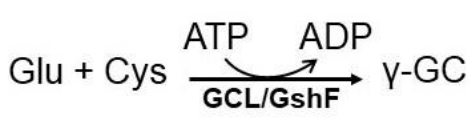

\begin{tabular}{|c|c|c|c|c|c|c|}
\hline \multirow{2}{*}{ Enzyme type } & \multicolumn{3}{|c|}{$K_{\mathrm{m}}(\mathrm{mM})$} & \multicolumn{3}{|c|}{$k_{\text {cat }}\left(\mathbf{s}^{-1}\right)$} \\
\hline & Glu & Cys & ATP & Glu & Cys & ATP \\
\hline $\mathrm{P} 22-\mathrm{GCL}_{\mathrm{s}}$ & 1.645 & 4.297 & 0.1790 & 4.545 & 5.189 & 5.410 \\
\hline P22-GCL & 1.544 & 3.746 & 0.1865 & 5.365 & 5.900 & 6.481 \\
\hline
\end{tabular}

Table S3. Steady-state kinetic constants for synthesis of $\gamma$-GC from Glu, Cys, and ATP, using a different batch of $\mathrm{P} 22-\mathrm{GCL}_{\mathrm{s}}$ and $\mathrm{P} 22-\mathrm{GCL}_{\mathrm{l}}$, determined by PK-LDH assay. 


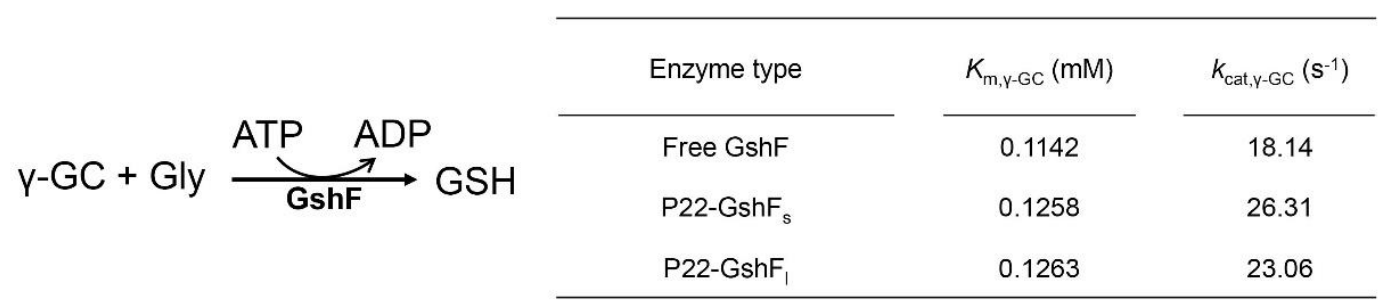

Table S4. Steady-state kinetic constants for synthesis of GSH catalyzed by GshF from $\gamma$-GC, 350 $\mathrm{mM}$ Gly, and $5 \mathrm{mM}$ ATP, determined by $\mathrm{mBBr}$ assay (supplemental to supplementary figure 5).

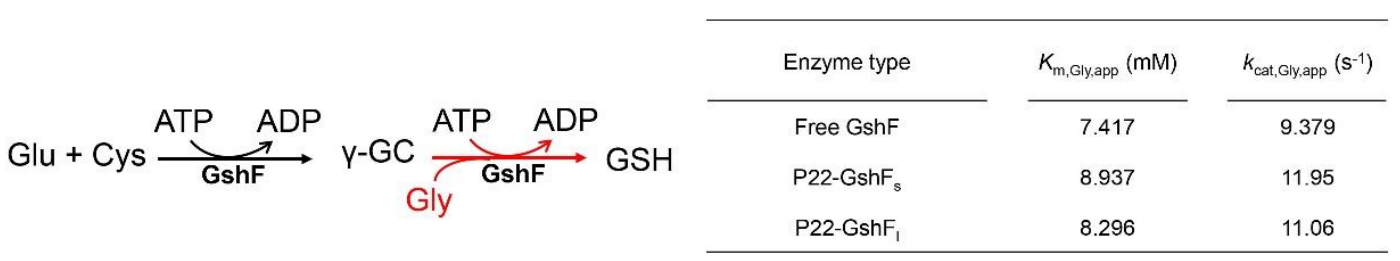

Table S5. Apparent kinetic constants for the second step (indicated in red arrows) of the complete GSH biosynthesis catalyzed by GshF from $50 \mathrm{mM}$ Glu, $2 \mathrm{mM}$ Cys, $5 \mathrm{mM}$ ATP, and variable concentration of Gly, determined by $\mathrm{mBBr}$ assay. 


\section{Supplementary Methods}

\section{Cloning}

GCL and GshF fused to truncated SP (amino acid 239-303) were cloned into pBAD/His A vector. To obtain linearized pBAD His A vector, a $50 \mu \mathrm{L}$ polymerase chain reaction (PCR) system was prepared containing $9.5 \mathrm{ng} \mathrm{pBAD} / \mathrm{His} \mathrm{A}$ vector plasmid (Invitrogen), $0.5 \mu \mathrm{M}$ primers (for both forward and reverse primer, see supporting information for sequences; Eurofins) and $25 \mu \mathrm{L} \mathrm{KOD}$ Hot Start Master Mix (EMD Millipore). The PCR was carried out using Thermo Scientific Arktik thermal cycler $\left(95^{\circ} \mathrm{C}\right.$ for $2 \mathrm{~min} ; 95^{\circ} \mathrm{C}$ for $20 \mathrm{sec}, 60^{\circ} \mathrm{C}$ for $10 \mathrm{sec}, 68^{\circ} \mathrm{C}$ for $4 \mathrm{~min}, 35 \mathrm{cycles} ; 68^{\circ} \mathrm{C}$ for $10 \mathrm{~min} ; 4^{\circ} \mathrm{C}$ hold). The PCR product was digested by Dpn I (100 U, NEB) at $37^{\circ} \mathrm{C}$ for $17.5 \mathrm{hrs}$ to degrade the template circular vector, followed by thermal denaturation of Dpn I at $80^{\circ} \mathrm{C}$ for $20 \mathrm{~min}$ and purification using QIAquick PCR Purification Kit.

The genes (g-blocks) of GCL and GshF were designed and ordered from Integrated DNA Technologies (see supporting information for sequences). The linearized $\mathrm{pBAD} / \mathrm{His} \mathrm{A}$ vector and insert genes (g-blocks) were assembled at $50^{\circ} \mathrm{C}$ for 1 hour in a $10 \mu \mathrm{L}$ reaction system, containing vector (5 ng), inserts (1.5 ng g-block A and $1.4 \mathrm{ng}$ g-block B for GCL; or $1.8 \mathrm{ng}$ g-block C and 1.4 ng g-block D for GshF) and $5 \mu \mathrm{L}$ NEBuilder HiFi DNA Assembly Master Mix. The assembly products were transformed into $25 \mu \mathrm{L}$ E. cloni 10G CLASSIC Electrocompetent Cells (Lucigen) by electroporation using Eppendorf Eporator. Then $400 \mu \mathrm{L}$ Expression Recovery Medium (Lucigen) was added to the cells, which was then incubated at $37^{\circ} \mathrm{C}$ with shaking for $50 \mathrm{~min}$. The cells were selected by LB agar plates with ampicillin $\left(0.05 \mathrm{mg} \mathrm{mL}^{-1}\right)$, and the selected colonies were inoculated in $5 \mathrm{~mL} \mathrm{LB}$ broth with antibiotics and incubated at $37^{\circ} \mathrm{C}$ with $200 \mathrm{rpm}$ shaking overnight. The plasmid DNA was extracted using QIAprep Spin Miniprep Kit (Qiagen). The sequences of the plasmids were validated by DNA sequencing services provided by Eurofins and ACGT, Inc. The primers for DNA sequencing were universal primers or deigned based on GCL/GshF enzyme sequence (see supporting information for sequences).

\section{Protein Production}

The plasmids $\mathrm{pBAD} / \mathrm{His} \mathrm{A}-\mathrm{GCL}$ or $\mathrm{pBAD} / \mathrm{His} \mathrm{A}-\mathrm{GshF}$, with or without pRSF Duet-P22 CP, ${ }^{2}$ was transformed into $25 \mu \mathrm{L}$ E. cloni EXPRESS BL21(DE3) Electrocompetent Cells (Lucigen). The transformed cells were selected by antibiotics $\left(0.05 \mathrm{mg} \mathrm{mL}^{-1}\right.$ ampicillin with or without $0.03 \mathrm{mg}$ $\mathrm{mL}^{-1}$ kanamycin), similar with the transformation mentioned in the cloning section. The selected colonies were inoculated in $15 \mathrm{~mL}$ LB broth with antibiotics and incubated at $37^{\circ} \mathrm{C}$ with $200 \mathrm{rpm}$ shaking overnight. $5 \mathrm{~mL}$ of the overnight culture was added to $1 \mathrm{~L} \mathrm{LB}$ broth with antibiotics for scale-up, and incubated at $37^{\circ} \mathrm{C}$ with $220 \mathrm{rpm}$ shaking for $2 \mathrm{hrs}$. The LB broth was then spiked with another $0.1 \mathrm{mg} \mathrm{mL}^{-1}$ ampicillin, and further incubated at $37^{\circ} \mathrm{C}$ with $220 \mathrm{rpm}$ shaking until $\mathrm{OD}_{600}$ reached 0.5 to 0.7 . L-arabinose was then added to $0.1 \%(\mathrm{w} / \mathrm{v})$ for the induction of desired proteins, followed by the incubation at $30^{\circ} \mathrm{C}$ with $225 \mathrm{rpm}$ shaking for $5 \mathrm{hrs}$ before harvest. IPTG was added to $0.3 \mathrm{mM}$ to induce $\mathrm{CP}$ when $\mathrm{L}$-arabinose was added (for P22-GCL $\mathrm{G}_{\mathrm{s}}$ and $\mathrm{P} 22-\mathrm{GshF}_{\mathrm{s}}$ ), or two hours after L-arabinose was added (for $\mathrm{P} 22-\mathrm{GCL}_{1}$ and $\mathrm{P} 22-\mathrm{GshF}_{1}$ ). Cells were harvested by centrifugation at $4500 \mathrm{rpm}$ for $15 \mathrm{~min}$ at $4^{\circ} \mathrm{C}$, and stored in $-80^{\circ} \mathrm{C}$. The proteins (free $\mathrm{GCL}$, free GshF, P22-GCL, $\mathrm{P} 22-\mathrm{GshF}_{1}$, and empty P22) free of lipopolysaccharides was also produced in ClearColi BL21(DE3) Electrocompetent Cells (Lucigen) for in vitro tissue culture work, and the method was the same as 
mentioned above, except that the scaled-up culture was incubated $30^{\circ} \mathrm{C}$ with $225 \mathrm{rpm}$ shaking overnight after inducer(s) addition and before harvest.

\section{Protein Purification}

The cell pellet was resuspended in 20-40 $\mathrm{mL}$ lysis buffer $\left(50 \mathrm{mM} \mathrm{NaPO}_{4}, 100 \mathrm{mM} \mathrm{NaCl}, \mathrm{pH} 7\right.$ for P22 VLPs, or pH 7.8 for free enzymes), followed by supplementing with lysozyme (1.5 mg; Sigma-Aldrich), DNase (2 mg; Sigma-Aldrich), and RNase (3 mg; Sigma-Aldrich). The cell suspension was then rocked for $30 \mathrm{~min}$ before sonication ( $2 \mathrm{~min}$ at 50\% amplitude; Branson Digital Sonifier) twice on ice. The cell lysate was cleared by centrifugation $\left(12000 \mathrm{rpm}, 4^{\circ} \mathrm{C}, 45 \mathrm{~min}\right)$ for purification.

For free enzymes, the cell lysate was filtered through $0.22 \mu \mathrm{m}$ membrane followed by purification using $\mathrm{Ni}^{2+}$-NTA column (Roche) on BioRad Biologic Duoflow FPLC. An imidazole gradient from 0 to $500 \mathrm{mM}$ in lysis buffer was applied to the column, and the protein of interest was eluted at $\sim 120 \mathrm{mM}$ imidazole, collected and then dialyzed into lysis buffer ( $\mathrm{pH}$ 7.0). For P22 VLPs, the cell lysate was subjected to $35 \%(\mathrm{w} / \mathrm{v})$ sucrose cushion and ultracentrifugation using Thermo Scientific Sorvall WX Ultra Series Centrifuge at $45000 \mathrm{rpm}, 50 \mathrm{~min}, 4^{\circ} \mathrm{C}$. The pellet was then resuspended in lysis buffer, centrifuged $(13200 \mathrm{~g}, 10 \mathrm{~min}$, RT), filtered through $0.45 \mu \mathrm{m}$ membrane, and purified by Sephacryl S-500 (GE Healthcare Life Sciences) column using BioRad Biologic Duoflow FPLC (lysis buffer as elution buffer). The purified VLPs were then subjected to ultracentrifugation without sucrose cushion, resuspension and Sephacryl S-500 column again in the same condition. The purified proteins were stored at $4^{\circ} \mathrm{C}$ temporarily. Glycerol was then added to a final concentration of $15 \%$, and the proteins were frozen in liquid nitrogen and stored at $-80^{\circ} \mathrm{C}$. Before being used, the frozen proteins were thawed, centrifuged at $13000 \mathrm{rpm}, 10 \mathrm{~min}, 4^{\circ} \mathrm{C}$ to remove all aggregates, and diluted to suitable buffers (at least 10-time dilution).

\section{SDS-PAGE and Densitometry Analysis}

The purity of the proteins was analyzed by $10 \%$ sodium dodecyl sulfate-polyacrylamide gel electrophoresis (SDS-PAGE), which was stained by Coomassie Brilliant Blue. To calculate the packing density of the enzymes in P22 VLPs by densitometry analysis, an gradient in amount of CP (P22 VLP empty shell; ${ }^{2}$ 60, 120, 180, 240, and 300 pmol in monomer) and free enzyme (6, 12, 18, 24 , and 30 pmol in monomer) were loaded onto SDS-PAGE to make calibration curves for densitometry analysis. P22 VLPs encapsulated with enzymes were also loaded onto the gel with a suitable amount so that the amount of $\mathrm{CP}$ and enzyme is within the ranges of the calibration curves. ImageJ $1.51 \mathrm{j} 8$ software $^{3}$ was used to obtain the line scan profiles of protein bands on the gel, which were then analyzed by Igor Pro 6.37 to find out the integral band density of CP and enzyme. The calibration curves were made between the protein concentration and the integral band density, and the concentration of CP and enzyme of the P22 VLPs was then determined, which allowed us to find out the $[\mathrm{CP}] /[$ enzyme] ratio and the enzyme packing density (Table S1) assuming each capsid consists of 420 copies of CP.

\section{Mass Spectrometry}

The purified proteins were diluted to $\sim 1 \mathrm{mg} \mathrm{mL}^{-1}$ (for free enzymes) or $A_{280}$ at 1.5-2.0 (for P22 VLPs), and sent to the service of LC-MS determination of an intact protein molecular weight provided by Laboratory for Biological Mass Spectrometry at Indiana University. 


\section{Determination of Protein Concentration}

The protein concentration was determined by $A_{280}$ measurement and enzyme packing density calculated from SEC-MALS results, unless specially indicated. As for $A_{280}$ measurement, $30 \mu \mathrm{L}$ of sample was mixed with $90 \mu \mathrm{L}$ guanidine hydrochloride $(\mathrm{GdHCl}, 6 \mathrm{M})$ with a final $\mathrm{GdHCl}$ concentration of $4.5 \mathrm{M}$ to remove the light scattering contribution from native P22 capsids. The absorbance at $280 \mathrm{~nm}$ was measured using Agilent Technology Cary $8454 \mathrm{UV}$-vis, corrected by the background of $4.5 \mathrm{M} \mathrm{GdHCl}$ in the same buffer. The concentration of free enzymes was calculated by

$$
A_{280}=\varepsilon_{\text {enzyme }}[\text { enzyme }] l D,
$$

where pathlength $l$ is $1 \mathrm{~cm}$, dilution factor $\mathrm{D}$ is 0.25 , and $\varepsilon_{\text {enzyme }}$ is $106690 \mathrm{M}^{-1} \mathrm{~cm}^{-1}$ (GCL) or 73690 $\mathrm{M}^{-1} \mathrm{~cm}^{-1}$ (GshF). Note that the SP part was cleaved in free enzymes and excluded in calculating the extinction coefficients. The total concentration of enzyme encapsulated in P22 VLPs was calculated by

$$
A_{280}=\left(\varepsilon_{\text {enzyme }}[\text { enzyme }] l+\varepsilon_{\mathrm{CP}}[\mathrm{CP}] l\right) D=\left(\varepsilon_{\text {enzyme }}+\varepsilon_{\mathrm{CP}} \frac{420}{\text { packing density }}\right)[\text { enzyme }] l D,
$$

where pathlength $l$ is $1 \mathrm{~cm}$, dilution factor $\mathrm{D}$ is $0.25,420$ is the copy number of CP per P22 VLP capsid, packing density is calculated from MALS results (Table 1 ), $\varepsilon_{\mathrm{CP}}$ is $44920 \mathrm{M}^{-1} \mathrm{~cm}^{-1}$, and $\varepsilon_{\text {enzyme }}$ is $108180 \mathrm{M}^{-1} \mathrm{~cm}^{-1}$ (GCL) or $75180 \mathrm{M}^{-1} \mathrm{~cm}^{-1}$ (GshF).

When indicated, Bradford assay was also used to determine protein concentration. Each assay was carried out by adding $75 \mu \mathrm{L}$ Coomassie protein assay reagent (Thermo Scientific) to $75 \mu \mathrm{L}$ protein sample containing $4.5 \mathrm{M} \mathrm{GdHCl}$, followed by incubation at $10-20 \mathrm{~min}$ at room temperature and signal reading by Cytation 3 plate reader at $595 \mathrm{~nm}\left(S_{595}\right)$, which was corrected from corresponding background. The calibration curves of the three standard proteins were made by linear regression passing through origin. The standard protein samples used were free GCL, GshF, and CP (P22 VLP empty shell ${ }^{2}$ ), whose concentrations were determined by $A_{280}$ under denatured condition (4.5 M GdHCl mentioned above). The total concentration of enzymes encapsulated in P22 VLPs was determined by

$$
S_{595}=S_{595, \text { enzyme }}+S_{595, \mathrm{CP}}=(\mathrm{a}[\text { enzyme }]+\mathrm{b}[\mathrm{CP}]) \mathrm{D}=\left(\mathrm{a}+\mathrm{b} \frac{420}{\text { packing density }}\right)[\text { enzyme }] \mathrm{D},
$$

where a (enzyme) and $\mathrm{b}(\mathrm{CP})$ are the slopes of the developed calibration curves, dilution factor $\mathrm{D}$ is $0.5,420$ is the copy number of CP per P22 VLP capsid, packing density is calculated from densitometry results (Table S1).

\section{Size-exclusion Chromatography Coupled with Multiangle Light Scattering (SEC- MALS)}

The P22 VLPs were centrifuged at $13200 \mathrm{rpm}$ for $10 \mathrm{~min}$ at room temperature, and the supernatant was used for analysis. For each analysis, $25 \mu \mathrm{L}$ P22 VLPs with $A_{280}$ at 1.5-2.0 was injected, separated by WTC-200S $5 \mu \mathrm{m}, 2000 \AA, 7.8 \mathrm{~mm} \times 300 \mathrm{~mm}$ (Wyatt Technologies) sizeexclusion column (SEC) utilizing an Agilent 1200 HPLC system, and analyzed by a Wyatt HELEOS multi-angle laser light scattering (MALS) detector and an Optilab rEX differential refractometer (Wyatt Technology Corporation). The mobile phase was $50 \mathrm{mM} \mathrm{NaPO}_{4}(\mathrm{pH} 7.2$ ) with $100 \mathrm{mM}$ $\mathrm{NaCl}$ and $200 \mathrm{ppm} \mathrm{NaN}$, and the flow rate was $0.7 \mathrm{~mL} \mathrm{~min}^{-1}$. The data were processed using Astra 5.3.14 software (Wyatt Technology Corporation) to get number-average molecular weights. 
The average molecular weight of P22 empty shell was subtracted from that of P22 nanoreactors to determine total molecular weight contribution from encapsulated enzymes per capsid, which was then divided by the molecular weight of a single enzyme copy (87856 Da for GCL, and $95465 \mathrm{Da}$ for GshF) to get the enzyme copy number per capsid (i.e. enzyme packing density).

\section{Local Protein Concentration Calculation}

The local enzyme concentration in P22 capsid was calculated by

$$
\text { Local protein concentration }=\frac{m}{V}=\frac{\text { packing density } \times\left(\mathrm{MM} / \mathrm{N}_{\mathrm{A}}\right)}{V},
$$

where $m$ is the total molecular weight of encapsulated enzyme per capsid, $V$ is the interior volume of a single P22 VLP $\left(46450 \mathrm{~nm}^{3}\right),{ }^{4} \mathrm{MM}$ is the molar mass of the encapsulated enzyme $(87856.29 \mathrm{~g}$ $\mathrm{mol}^{-1}$ for GCL, and $95464.98 \mathrm{~g} \mathrm{~mol}^{-1}$ for GshF), $N_{\mathrm{A}}$ is Avogadro constant $\left(6.022 \times 10^{23} \mathrm{~mol}^{-1}\right)$, and packing densities are listed in Table 1 and Table S1.

\section{Transmission Electron Microscopy (TEM)}

Protein samples ( $\left.10 \mu \mathrm{L}, A_{280} 0.5-0.6\right)$ were applied to 400 mesh carbon-coated copper grids. Excess sample was wicked away with filter paper. The grid was then washed twice with $10 \mu \mathrm{L} \mathrm{H}_{2} \mathrm{O}$ and further stained with $10 \mu \mathrm{L} 2 \%$ uranyl acetate for 2 min. Excess stain was wicked away with filter paper. The images were taken under JEOL JEM-1010 transmission electron microscope. The particle size (diameter) of VLPs were measured by analyzing the images using ImageJ $1.51 \mathrm{j} 8 .^{3}$

\section{SYPRO Orange dye-based Thermal Shift Assay}

Enzyme samples in phosphate buffer ( $50 \mathrm{mM} \mathrm{NaPO}_{4}, 100 \mathrm{mM} \mathrm{NaCl}, 15 \%$ glycerol, $\mathrm{pH}$ 7.0) were adjusted to a total enzyme concentration of $1 \mu \mathrm{M}$. Empty P22 was prepared in the sample buffer and adjusted to the same capsid concentration as $\mathrm{P}_{22}-\mathrm{GCL}_{1}(126 \mathrm{nM})$ or P22-GshF $\mathrm{F}_{1}(105$ $\mathrm{nM})$. To prepare samples for thermal shift assay, $0.8 \mu \mathrm{L}$ SYPRO Orange Protein Gel Stain (Sigma) was added to $1000 \mu \mathrm{L}$ protein sample. Then $25 \mu \mathrm{L}$ assay mixture was analyzed using StepOnePlus Real-Time PCR System (Applied Biosystems) with temperature elevating from $25{ }^{\circ} \mathrm{C}$ to $95{ }^{\circ} \mathrm{C}$ with a ramp rate of $1{ }^{\circ} \mathrm{C}$ per $2 \mathrm{~min}$. The results of the assays were analyzed by Protein Thermal Shift Software (Thermo Fisher Scientific). 


\section{Supplementary Discussion}

\section{Methods of determining packing density inside P22 capsids}

The total enzyme concentration is important for calculating enzyme kinetics, but its determination has been challenging when the enzymes are encapsulated in protein capsids. The concentration of encapsulated enzymes can be deduced from three factors of the samples, including the total protein concentration measurement, the copy number ratio of enzyme to $\mathrm{CP}$ in the solution, and how much each copy of $\mathrm{CP}$ and enzyme contributes to the total protein concertation measurement. For example, a widely-used method was applied to get the kinetic data shown in Table 2 and Figure S4, where total protein concentration measurement was $A_{280}$, enzyme:CP copy ratio was calculated from packing density determined by MALS results (assuming each capsid consists of 420 copies of CP, Table 1), and contribution of each CP and enzyme copy to $A_{280}$ was defined by their respective extinction coefficients at $280 \mathrm{~nm}$ defined (see Methods for calculations). The inaccuracy or imprecision from either one of the three factors may lead to a misestimate on the total enzyme concentration, causing a less accurate interpretation on the catalytic behavior of encapsulation. Given the facts that protein-specific extinction coefficients at $280 \mathrm{~nm}$ can be estimated from sequences, and the theories underlying UV-vis absorption and MALS are independent from each other, there are high accuracy and precision expected as long as the loading density can be accurately estimated. However, the limitation of the MALS technique dictates the error of average molecular weight of capsids and consequently the error of the loading density could reach as high as approximately $10 \% .{ }^{5}$ Another way to determine total enzyme concentration is to couple Bradford assay (a total protein measurement) with densitometry analyses of protein bands from electrophoresis such as SDS-PAGE and Western Blot (an estimation of enzyme:CP ratio). The correlation between Bradford assay and SDS-PAGE is supposed to be good, given that both techniques utilize the same dye, Coomassie Brilliant Blue, for quantification. However, as different proteins may have different affinities for the dye, calibration curves of standard proteins need to be generated for densitometry analyses (Figure S3) and Bradford assay, respectively, to figure out the contribution of each $\mathrm{CP}$ and enzyme copy to the colorimetry. In our case, this method could be even less accurate in our case, because the calibration curves were generated using free GCL and GshF, whose SP fusion was cleaved during protein production and purification. Furthermore, the errors generated in densitometry analyses (Table S1) are much more significant than MALS data (Table 1). Despite all these shortcomings, we analyzed the same set of kinetics data using this method (Table S2), as a parallel comparison to the first method mentioned above $\left(A_{280}\right.$-MALS, Table 2$)$. The kinetic constants from the two different methods are pretty close to each other (mostly within $10 \%$ difference, except that the $k_{\text {cat }}$ values for the second step of GSH biosynthesis by GshF are approximately $30 \%$ off), indicating a high probability that the results calculated from both methods reflect the overall behavior of the encapsulated enzymes. Other methods in quantification of total concentration of encapsulated proteins, such as fluorescence quantification of fluorescent protein, were also mentioned in determining the concentration of encapsulated proteins in some literature, ${ }^{6}$, ${ }^{7}$ but not applicable in our case. Considering that all these methods have limitations and the first method mentioned above probably provides the best estimation, we based our discussions on the packing densities calculated from the first method (i.e., $A_{280}$, enzyme:CP ratio from MALS results, and sequence-based extinction coefficients) unless specially noted. 


\section{Packing density of GshF in protein crystal}

The packing density was calculated based on the crystal structure of GshF (PDB: 3LN7). ${ }^{8}$ The protein concentration of the crystal

$$
[\mathrm{E}]=\frac{m_{\mathrm{u}}}{V_{\mathrm{u}}}=\frac{n \frac{\mathrm{MW}}{N_{\mathrm{A}}}}{a b c \cdot \sin \beta},
$$

where $m_{\mathrm{u}}$ is the mass of GshF in a single unit cell, $V_{\mathrm{u}}$ is the volume of a single unit cell, $n$ is the number of GshF protomers in a single unit cell (8), MW is the molar mass of GshF ( $85862.29 \mathrm{~g} / \mathrm{mol})$, $N_{\mathrm{A}}$ is Avogadro constant $\left(6.02214076 \times 10^{23} \mathrm{~mol}^{-1}\right)$. The unit cell parameters of the protein crystal are $\mathrm{a}=205.24 \AA, \mathrm{b}=87.07 \AA, \mathrm{c}=145.98 \AA$, and $\beta=126.53^{\circ} .{ }^{8}$ Plugging all these numbers into the equation will get $[\mathrm{E}] \approx 544 \mathrm{mg} / \mathrm{ml}$.

From the structure, the shortest intermolecular (dimer-dimer) distance, i.e. the distance between the two closest atoms originated from two different dimers, is more than $17 \AA$. And the shortest distance between GCL and GS active sites is much longer (about $70 \AA$, even taking no account of the angles between the active sites).

\section{Data analysis of Figure 5}

The main conclusion of Figure 5 is that the P22 nanoreactors are capable of protecting cells from oxidative stress. In this figure, Cys, which had almost no protective effect, serves as a negative control. Meanwhile, both $\gamma$-GC and GSH, known for protection against oxidative stress, have a significant difference (i.e. protective effect) from Cys suggested by t-tests, acting as positive controls to make sure the experiment design could work as an effective model to reflect any protection or no protection against oxidative stress. With these controls, whether a treatment has protective effect or not against oxidative stress could be examined by seeing whether there is a significant difference from the Cys group or not. If there is a significant difference, it is indicated by *, **, or *** in Figure 5.

Further analyses on these data were focused on 1) whether the protective effect of P22 nanoreactors are due to the encapsulated enzymes, and 2) whether there is any advantage of P22 nanoreactors in protective effect compared to GSH. Therefore, a one-way analysis of variance (ANOVA) test was carried out among the following groups: Cys, P22-GCL, GSH, and empty P22. the $P$ value of the test was 0.0007 , which means there is a significant difference among these groups. Moving forward, to determine whether there is any significant difference between each of these groups, a Tukey's multiple comparison test was carried out with results summarized below:

\begin{tabular}{|l|l|l|}
\hline Comparison & $P$ value & \\
\hline Cys vs. GSH & 0.0161 & $\#$ \\
\hline Cys vs. P22-GCL & 0.0009 & $\# \# \#$ \\
\hline Cys vs. Empty P22 & 0.6568 & n.s. \\
\hline P22-GCL vs GSH. & 0.5903 & n.s. \\
\hline P22-GCL vs. Empty P22 & 0.0126 & $\#$ \\
\hline GSH vs. Empty P22 & 0.1657 & n.s. \\
\hline
\end{tabular}

There are two main deductions of this test. 1) There is a significant difference between P22-GCL and empty P22 (indicated by \# in Figure 5), which suggests the protective effect of P22-GCL is mainly from the encapsulated GCL. 2) There is no significant difference between P22-GCL and GSH (indicated by n.s. in Figure 5), which suggests that the protective effect afforded by the nanoreactors is similar to GSH. 
We did similar tests on P22-GshF. Unfortunately, P22-GshF is not significantly different from either empty P22 or GSH, which might be due to limited number of data points and non-specific protective effect by empty P22. 


\title{
Sequence Information
}

\author{
1. Primers for $\mathrm{pBAD} / \mathrm{His} \mathrm{A}$ vector linearization \\ Forward primer: 5'-GAGCTCGAGATCTGCAGCTGGTACCATATGG-3' \\ Reverse primer: 5'-GGTTAATTCCTCCTGTTAGCCCAAAAAACGG-3'
}

\section{G-blocks}

The sequences that are complementary with $\mathrm{pBAD} / \mathrm{His} \mathrm{A}$ vector are labeled red.

Start and stop codons are highlighted in yellow.

Hexahistidine tag is labeled orange.

The sequences of GCL/GshF enzyme are labeled green, with overlapping sequences between the two g-blocks are doubly underlined, and the sequences designed for DNA sequencing are highlighted blue.

The linker between GCL/GshF enzyme and P22 truncated scaffold protein is underlined, where TEV cleavage site is in bold.

P22 truncated scaffold protein (239-303) is labeled in blue.

\section{G-block A (the first g-block for GCL-SP)}

CCGTTTTTTGGGCTAACAGGAGGAATTAACCATGGGCAGCAGCCATCACCATCATCA CCACAGCCAGGGTTTGTTAGCCCTTGGGACTCCATTACAGTGGTTTGAGAGCCGTACT TACAACGAGCACATCCGCGATGAAGGCATCGAGCAACTTTTATATATTTTCCAAGCTG CGGGCAAGCGTGACAATGACCCTCTTTTTTGGGGGGACGAGTTAGAATACATGGTGG TTGACTTTGATGATAAAGAACGTAATTCCATGCTGGACGTATGCCACGACAAGATTCT GACCGAACTTAACATGGAAGACAGTTCGTTATGCGAGGCCAACGATGTGAGTTTCCA CCCCGAGTACGGTCGCTATATGTTAGAAGCTACTCCCGCGAGTCCCTACTTAAATTAC GTAGGCAGCTACGTCGAAGTCAATATGCAGAAGCGTCGCGCAATTGCCGAATATAAG TTATCGGAATACGCTCGTCAGGACTCAAAAAATAATCTTCATGTCGGCTCACGTTCTG TGCCGCTTACCCTTACGGTTTTCCCTCGCATGGGCTGCCCTGACTTTATCAATATTAAA GATCCGTGGAACCACAAGAACGCAGCTAGTCGTTCCTTGTTCTTACCAGACGAAGTG ATTAATCGTCACGTGCGTTTTCCTAACTTAACTGCTTCAATTCGTACTCGTCGCGGGG AAAAAGTGTGTATGAATGTCCCAATGTACAAGGACATCGCCACGCCGGAGACGGATG ATTCGATCTATGATCGCGATTGGTTTCTTCCGGAGGACAAAGAGGCTAAACTGGCTTC TAAACCTGGCTTCATCTATATGGACTCAATGGGCTTTGGTATGGGGTGTTCATGTCTTC AGGTGACCTTCCAAGCCCCAAACATCAACAAGGCGCGCTACTTGTATGATGCGTTAG TAAATTTCGCGCCGATTATGCTTGCATTTTCGGCCGCCGCACCGGCCTTCAAAGGGTG GCTGGCGGACCAAGACGTACGTTGGAACGTAATCTCCGGTGCGGTAGACGACCGTAC ACCAAAGGAGCGCGGTGTTGCTCCTTTGCTTCCTAAGTATAACAAGAACGGATTTGG GGGAATTGCGAAGGACGTACAAGATAAGGTGCTTGAAATCCCCAAATCGCGTTACTC CTCAGTTGACTTGTTTCTGGGTGGCTCAAAGTTCTTCAACCGTACATATAATGATACC AATGTTCCCATTAACGAAAAGGTCCTTGGCCGCCT

\section{G-block B (the second g-block for GCL-SP)}


TCCCATTAACGAAAAGGTCCTTGGCCGCCTGCTGGAGAATGACAAGGCACCCCTTGA CTACGATCTGGCAAAGCATTTCGCCCACTTATATATCCGCGACCCAGTCTCGACATTT GAGGAGCTGTTGAACCAAGACAACAAAACCTCATCTAATCACTTTGAAAACATCCAA AGCACAAACTGGCAGACTTTGCGCTTCAAACCGCCGACCCAACAGGCCACCCCTGAT AAGAAGGATAGCCCTGGCTGGCGTGTCGAATTCCGCCCTTTCGAGGTCCAATTGTTAG ATTTCGAGAACGCGGCTTATTCCGTGCTTATTTATTTAATTGTAGATAGTATTCTTACT TTTAGTGACAATATTAATGCGTACATTCACATGTCTAAGGTATGGGAAAATATGAAGA TTGCGCATCATCGTGATGCTATCCTGTTCGAGAAATTCCACTGGAAAAAATCCTTCCG CAACGACACAGACGTCGAGACTGAGGACTACTCAATTTCGGAAATCTTCCACAACCC GGAGAACGGCATTTTCCCCCAGTTTGTGACACCTATCTTATGTCAGAAGGGCTTTGTC ACAAAGGATTGGAAGGAACTGAAACACAGTTCTAAACACGAACGTCTGTACTATTAC CTTAAGCTGATTTCAGACCGCGCGAGCGGAGAATTGCCAACGACCGCAAAATTTTTTC GCAATTTCGTCTTGCAACATCCAGACTACAAGCACGATTCAAAAATTAGCAAGAGTA TTAACTACGATCTGTTGTCTACATGCGACCGCTTGACTCACTTGGACGACTCCAAGGG TGAACTGACGTCGTTCTTAGGAGCTGAAATTGCTGAATACGTCAAAAAGAACAAGCC ATCGATCGAGTCGAAGTGTGGCGCGGCAGGCGAAAACCTGTATTTCCAGAGCGGTG CGGCAGGCACGCGCTTATCGGAACGTCTTACTTTAAAACCGCGCGGCAAGCAGATTT CAAGTGCCCCCCATGCTGACCAGCCTATTACAGGCGATGTAAGTGCGGCGAATAAAG ATGCGATCCGCAAACAAATGGATGCTGCGGCCTCGAAGGGTGATGTGGAGACATACC GCAAATTGAAAGCGAAATTGAAGGGAATCCGCTAAGAGCTCGAGATCTGCAGCTGGT ACCATATGG

\section{G-block C (the first g-block for GshF-SP)}

CCGTTTTTTGGGCTAACAGGAGGAATTAACCATGGGCAGCAGCCATCACCATCATCACC ACAGCCAGAAAATCCAACACATTATCCACGAGAATCAACTGGGTCTTTTATTCCAACA AGGCTCATTTGGCCTTGAGAAAGAGTCGCAGCGCGTGACCGCCGATGGAGCGATCGT GACCACTCCACATCCAGCGGTGTTTGGCAATCGCCGCTATCACCCTTACATCCAAACCG ATTTTGCCGAGTCGCAATTAGAACTTATTACACCCCCCACTAAGAAGCTGGAAGATACT TTTCGTTGGCTGTCCGTAATCCACGAGGTCGTTCAGCGTTCTCTGCCGGAGGAGGAAT ATATTTTCCCTCTTTCGATGCCTGCCGGGCTTCCGGCAGAGGAACAGATCCGTGTGGCT CAGTTGGATAATCCGGAGGACGTTGCGTACCGCGAATATCTGGTAAAGATTTATGGAAA GAATAAACAGATGGTAAGTGGGATCCATTACAACTTCCAACTTTCCCCCGACCTGATTA CGCGTTTGTTTCGTTTGCAAAATGAGTACCAAAGCGCCGTGGATTTTCAAAACGATCTG TACCTTAAGATGGCCAAAAATTTTTTACGCTATCAATGGATTCTGCTGTATCTGTTGGCA GCGACTCCTACAGTAGAGAGCGCCTATTTCAAGGATGGCAGCCCATTGGCTAAGGGGC AGTTCGTGCGTTCACTTCGTAGCAGCCAATATGGGTACGTCAATGACCCCGAAATTAAT GTATCATTTGACTCAGTGGAGAAGTATGTCGAGTCGCTGGAACATTGGGTAAGCACAG GGAAATTGATCGCAGAAAAGGAATTTTATAGCAATGTGCGTCTGCGTGGCGCGAAAAA AGCCCGCGAATTCTTGACCACAGGGATCCAGTATCTGGAGTTCCGCCTTTTTGATCTTA ATCCTTTCGAAATTTACGGAATCTCACTGAAAGATGCTAAGTTCATCCACGTATTCGCCT TATTCATGATCTGGATGGACCATACTGCAGATCAAGAGGAAGTAGAGTTAGGGAAGGC GCGTTTGGCCGAGGTTGCCTTTGAGCACCCCTTGGAGAAGACAGCATACGCGGTTGAG GGCGAGTTGGTACTTCTTGAGTTATTGTCTATGCTGGAGCAGATCGGAGCAGAACCAG AATTATTTGAAATTGTCAAAGAAAAGCTTACGCAATTCACAGACCCAAGCAAAACTGT 
CGCTGGGCGTTTGGTCCGTGCAATCGAGCAGGCCGGGTCCGACCAGCAGCTGGGTGC CCAGCTTGCCCAACAATATAAAGCACAGGCTTTCGAACGCTTTTACGCATTATCAGCAT TCGACAACATGGAGTTGTCAACGCAAGCTTTGTTGTTCGACGTAATTCAAAAAGGGAT TCATACTGAGATTTTGGATGAGAATGACCAGTTCCTTTGCTTAAAGTACGGTG $\underline{\underline{A T C A C A}}$ TTGAATACGTGAAGAATGGTAATA

\section{G-block D (the second g-block 2 for GshF-SP)}

ATCACATTGAATACGTGAAGAATGGTAATATGACTTCTCACGATTCATACATTTCCCCAT TGATCATGGAGAACAAGGTCGTAACTAAGAAAGTACTTCAGAAAGCAGGATTTAATGT CCCGCAATCGGTGGAGTTTACGAGTTTGGAGAAAGCGGTAGCCAGTTACGCTTTATTC GAAAATCGCGCTGTAGTAATTAAGCCAAAATCTACTAATTACGGTTTAGGCATTACAATC TTTCAGCAAGGCGTGCAGAACCGCGAAGACTTCGCAAAAGCACTGGAAATTGCATTT CGCGAGGACAAGGAAGTAATGGTTGAAGATTACTTGGTTGGCACGGAGTATCGTTTCT TCGTTCTTGGCGATGAAACACTTGCCGTATTGTTACGCGTTCCCGCAAACGTTGTTGGG GATTCAGTGCACAGTGTTGCTGAATTGGTAGCGATGAAAAACGACCACCCTTTGCGCG GAGATGGGTCACGTACACCGTTGAAAAAAATCGCCCTGGGAGAGATTGAACAGCTGC AGCTTAAAGAGCAGGGATTGACGATCGATAGTATTCCGGCCAAAGACCAATTAGTACA GCTTCGTGCTAATTCCAACATCAGCACTGGAGGGGATAGTATTGATATGACTGACGAAA TGCACGAAAGCTACAAGCAGTTAGCTGTAGGAATTACCAAGGCGATGGGTGCTGCCGT CTGCGGCGTCGACTTAATTATTCCAGACCTGAAGCAGCCCGCTACCCCTAACTTAACCA GCTGGGGAGTAATTGAGGCAAATTTCAACCCCATGATGATGATGCATATCTTTCCATACG CCGGAAAGAGTCGTCGCTTAACCCAGAACGTCATCAAAATGCTGTTCCCAGAATTAGA GGGCGCGGCAGGCGAAAACCTGTATTTCCAGAGCGGTGCGGCAGGCACGCGCTTAT CGGAACGTCTTACTTTAAAACCGCGCGGCAAGCAGATTTCAAGTGCCCCCCATGCTGA CCAGCCTATTACAGGCGATGTAAGTGCGGCGAATAAAGATGCGATCCGCAAACAAATG GATGCTGCGGCCTCGAAGGGTGATGTGGAGACATACCGCAAATTGAAAGCGAAATTGA AGGGAATCCGCTAAGAGCTCGAGATCTGCAGCTGGTACCATATGG

\section{Primers for DNA Sequencing}

\section{GCL-SP}

5'-ATGCCATAGCATTTTTATCC-3' (pBAD Forward, a universal primer)

5'-GCTTCAATTCGTACTCGTCG-3'

5'-CGATCTGGCAAAGCATTTCG-3'

\section{GshF-SP}

5'-ATGCCATAGCATTTTTATCC-3' (pBAD Forward, a universal primer)

5'-CCTATTTCAAGGATGGCAGC-3'

5'-CGCTTTTACGCATTATCAGC-3'

5'-GATTTAATCTGTATCAGG-3' (pBAD Reverse, a universal primer)

\section{Protein Sequences}

The starting methionine (cleaved after translation, validated by LC-MS) and stop are highlighted in 
yellow.

Hexahistidine tag is labeled orange

The sequences of GCL/GshF enzyme are labeled green.

The linker between GCL/GshF enzyme and P22 truncated scaffold protein is in black, where TEV cleavage site is in bold.

P22 truncated scaffold protein (239-303) is in labeled in blue.

The part got cleaved in free enzymes, confirmed by mass spectrometry results, is underlined.

\section{GCL-SP (6xHis-GCL-TEV-SP 239-303)}

MGSSHHHHHHSQGLLALGTPLQWFESRTYNEHIRDEGIEQLLYIFQAAGKRDNDPLFWG DELEYMVVDFDDKERNSMLDVCHDKILTELNMEDSSLCEANDVSFHPEYGRYMLEATP ASPYLNYVGSYVEVNMQKRRAIAEYKLSEYARQDSKNNLHVGSRSVPLTLTVFPRMGCP DFINIKDPWNHKNAASRSLFLPDEVINRHVRFPNLTASIRTRRGEKVCMNVPMYKDIATPE TDDSIYDRDWFLPEDKEAKLASKPGFIYMDSMGFGMGCSCLQVTFQAPNINKARYLYDA LVNFAPIMLAFSAAAPAFKGWLADQDVRWNVISGAVDDRTPKERGVAPLLPKYNKNGF GGIAKDVQDKVLEIPKSRYSSVDLFLGGSKFFNRTYNDTNVPINEKVLGRLLENDKAPLD YDLAKHFAHLYIRDPVSTFEELLNQDNKTSSNHFENIQSTNWQTLRFKPPTQQATPDKKD SPGWRVEFRPFEVQLLDFENAAYSVLIYLIVDSILTFSDNINAYIHMSKVWENMKIAHHRD AILFEKFHWKKSFRNDTDVETEDYSISEIFHNPENGIFPQFVTPILCQKGFVTKDWKELKHS SKHERLYYYLKLISDRASGELPTTAKFFRNFVLQHPDYKHDSKISKSINYDLLSTCDRLTH LDDSKGELTSFLGAEIAEYVKKNKPSIESKCGAAGENLYFQSGAAGTRLSERLTLKPRGK QISSAPHADQPITGDVSAANKDAIRKQMDAAASKGDVETYRKLKAKLKGIR-

\section{GshF-SP (6xHis-GshF-TEV-SP 239-303)}

MGSSHHHHHHSQKIQHIIHENQLGLLFQQGSFGLEKESQRVTADGAIVTTPHPAVFGNRRY HPYIQTDFAESQLELITPPTKKLEDTFRWLSVIHEVVQRSLPEEEYIFPLSMPAGLPAEEQIRV AQLDNPEDVAYREYLVKIYGKNKQMVSGIHYNFQLSPDLITRLFRLQNEYQSAVDFQNDL YLKMAKNFLRYQWILLYLLAATPTVESAYFKDGSPLAKGQFVRSLRSSQYGYVNDPEINV SFDSVEKYVESLEHWVSTGKLIAEKEFYSNVRLRGAKKAREFLTTGIQYLEFRLFDLNPFEI YGISLKDAKFIHVFALFMIWMDHTADQEEVELGKARLAEVAFEHPLEKTAYAVEGELVLLE LLSMLEQIGAEPELFEIVKEKLTQFTDPSKTVAGRLVRAIEQAGSDQQLGAQLAQQYKAQ AFERFYALSAFDNMELSTQALLFDVIQKGIHTEILDENDQFLCLKYGDHIEYVKNGNMTS HDSYISPLIMENKVVTKKVLQKAGFNVPQSVEFTSLEKAVASYALFENRAVVIKPKSTNYG LGITIFQQGVQNREDFAKALEIAFREDKEVMVEDYLVGTEYRFFVLGDETLAVLLRVPANV VGDSVHSVAELVAMKNDHPLRGDGSRTPLKKIALGEIEQLQLKEQGLTIDSIPAKDQLVQL RANSNISTGGDSIDMTDEMHESYKQLAVGITKAMGAAVCGVDLIIPDLKQPATPNLTSWG VIEANFNPMMMMHIFPYAGKSRRLTQNVIKMLFPELEGAAGENLYFQSGAAGTRLSERLT LKPRGKQISSAPHADQPITGDVSAANKDAIRKQMDAAASKGDVETYRKLKAKLKGIR-

\section{P22 coat protein}

MALNEGQIVTLAVDEIIETISAITPMAQKAKKYTPPAASMQRSSNTIWMPVEQESPTQEGW DLTDKATGLLELNVAVNMGEPDNDFFQLRADDLRDETAYRRRIQSAARKLANNVELKVA NMAAEMGSLVITSPDAIGTNTADAWNFVADAEEIMFSRELNRDMGTSYFFNPQDYKKAG YDLTKRDIFGRIPEEAYRDGTIQRQVAGFDDVLRSPKLPVLTKSTATGITVSGAQSFKPVAW 
QLDNDGNKVNVDNRFATVTLSATTGMKRGDKISFAGVKFLGQMAKNVLAQDATFSVVR VVDGTHVEITPKPVALDDVSLSPEQRAYANVNTSLADAMAVNILNVKDARTNVFWADDAI RIVSQPIPANHELFAGMKTTSFSIPDVGLNGIFATQGDISTLSGLCRIALWYGVNATRPEAIG VGLPGQTA- 


\section{References}

[1] Kant, R., Llauró, A., Rayaprolu, V., Qazi, S., de Pablo, P. J., Douglas, T., and Bothner, B. (2018) Changes in the stability and biomechanics of $\mathrm{P} 22$ bacteriophage capsid during maturation, Biochim Biophys Acta Gen Subj 1862, 1492-1504.

[2] Selivanovitch, E., Koliyatt, R., and Douglas, T. (2019) Chemically Induced Morphogenesis of P22 Virus-like Particles by the Surfactant Sodium Dodecyl Sulfate, Biomacromolecules 20, 389-400.

[3] Schindelin, J., Arganda-Carreras, I., Frise, E., Kaynig, V., Longair, M., Pietzsch, T., Preibisch, S., Rueden, C., Saalfeld, S., Schmid, B., Tinevez, J. Y., White, D. J., Hartenstein, V., Eliceiri, K., Tomancak, P., and Cardona, A. (2012) Fiji: an open-source platform for biologicalimage analysis, Nat Methods 9, 676-682.

[4] Llauró, A., Luque, D., Edwards, E., Trus, B. L., Avera, J., Reguera, D., Douglas, T., Pablo, P. J., and Castón, J. R. (2016) Cargo-shell and cargo-cargo couplings govern the mechanics of artificially loaded virus-derived cages, Nanoscale 8, 9328-9336.

[5] Folta-Stogniew, E., and Williams, K. R. (1999) Determination of molecular masses of proteins in solution: Implementation of an HPLC size exclusion chromatography and laser light scattering service in a core laboratory, J Biomol Tech 10, 51-63.

[6] Han, X., and Woycechowsky, K. J. (2017) Encapsulation and Controlled Release of Protein Guests by the Bacillus subtilis Lumazine Synthase Capsid, Biochemistry 56, 6211-6220.

[7] Azuma, Y., Zschoche, R., and Hilvert, D. (2017) The C-terminal peptide of Aquifex aeolicus riboflavin synthase directs encapsulation of native and foreign guests by a cage-forming lumazine synthase, J Biol Chem 292, 10321-10327.

[8] Stout, J., De Vos, D., Vergauwen, B., and Savvides, S. N. (2012) Glutathione biosynthesis in bacteria by bifunctional GshF is driven by a modular structure featuring a novel hybrid ATP-grasp fold, J Mol Biol 416, 486-494. 